DOI: https://doi.org/10.24127/ajpm.v10i2.3519

\title{
PENGEMBANGAN BAHAN AJAR BERBENTUK VIDEO PEMBELAJARAN BERBASIS DATA COVID-19 UNTUK MENINGKATKAN KEWASPADAAN MAHASISWA TERHADAP HOAKS
}

\author{
Purna Bayu Nugroho', Badawi ${ }^{2}$, Agung Prihatmojo ${ }^{3 *}$ \\ ${ }^{1,2,3}$ Universitas Muhammadiyah Kotabumi, Lampung Utara, Indonesia \\ *Purna Bayu Nugroho, Universitas Muhammadiyah Kotabumi, Lampung Utara, Indonesia \\ E-mail: $\quad$ purnabayupvz@gmail.com ${ }^{\left.{ }^{*}\right)}$ \\ badawi@umko.ac.id $^{2)}$ \\ agung.prihatmojo@umko.ac.id ${ }^{3)}$
}

Received 30 January 2021; Received in revised form 11 June 2021; Accepted 29 June 2021

\begin{abstract}
Abstrak
Penelitian ini bertujuan untuk mengetahui: 1) kelayakan bahan ajar berbasis data covid-19 untuk meningkatkan kewaspadaan mahasiswa Muhammadiyah terhadap hoaks, dan (2) capaian pembelajaran mahasiswa Universitas Muhammadiyah Kotabumi terkait kewaspadaan terhadap hoaks. Penelitian ini menggunakan metode Research \& Development ( $\mathrm{R} \& \mathrm{D})$ dengan model pengembangan Borg \& Gall yang telah dimodifikasi sehingga hanya menggunakan 7 tahap saja. Prosedur pengembangan dalam penelitian ini mencakup: : (1) observasi dan pengumpulan informasi, (2) perencanaan desain produk, (3) pengembangan desain produk, (4) validasi desain produk, (5) perbaikan desain, (6) uji coba awal dan (7) revisi produk. Instrumen yang digunakan dalam penelitian ini berupa: pedoman wawancara, lembar validasi, angket tanggapan pengguna, serta tes kewaspadaam terhadap hoaks. Subjek penelitian pada tahap pengumpulan data adalah 12 mahasiswa sedangkan pada tahap ujicoba awal produk adalah 24 mahasiswa semester 3 prodi Pendidikan Matematika yang sedang menempuh matakuliah Statistika. Teknik analisis data dalam penelitian ini menggunakan pendekatan: (1) deskriptif kuantitatif untuk mengolah data skor dari penilaian ahli dan respon mahasiswa terhadap tes kewaspadaan terhadap hoaks, sedangkan (2) deskriptif kualitatif untuk mendeskripsikan data berupa: (a) komentar saran perbaikan dari ahli pada saat proses validasi serta (b) hasil wawancara pada saat melakukan observasi. Hasil penelitian ini menunjukkan bahwa: 1) Bahan ajar berbasis data covid-19 berbentuk video yang dikembangkan layak untuk digunakan dengan kategori penilaian sangat baik; dan 2) Capaian pembelajaran mahasiswa Universitas Muhammadiyah Kotabumi terkait kewaspadaan terhadap hoaks cukup baik.
\end{abstract}

Kata kunci: Bahan ajar; covid-19; hoaks; video dan waspada.

\begin{abstract}
This study aims to determine: 1) the feasibility of Covid-19 data-based teaching materials to increase awareness of Muhammadiyah students against hoaxes, and (2) the learning outcomes of Muhammadiyah Kotabumi University students regarding awareness of hoaxes. This study uses the Research \& Development $(R$ $\& D)$ method with the modified Borg \& Gall development model so that it only uses 7 stages. The development procedure in this study includes: (1) observation and information collection, (2) product design planning, (3) product design development, (4) product design validation, (5) design improvement, (6) initial trial and error. (7) product revision. The instruments used in this study were: interview guides, validation sheets, user response questionnaires, and tests for hoax alerts. The research subjects at the data collection stage were 12 students while at the initial trial stage the product was 24 students in the 3rd semester of Mathematics Education study program who were taking Statistics courses. Data analysis techniques in this study used the following approaches: (1) quantitative descriptive to process score data from expert assessments and student responses to the hoax awareness test, while (2) qualitative descriptive to describe data in the form of: (a) comments on suggestions for improvement from experts during the validation process and (b) the results of interviews during observations. The results of this study indicate that: 1) Covid-19 data-based teaching materials in the form of videos developed are suitable for use with very good assessment categories; and 2) The learning achievement of Muhammadiyah Kotabumi University students regarding awareness of hoaxes is quite good.
\end{abstract}

Keywords: Alert; covid-19; hoax; teaching materials; and video

This is an open access article under the Creative Commons Attribution 4.0 International License 
DOI: https://doi.org/10.24127/ajpm.v10i2.3519

\section{PENDAHULUAN}

Perkembangan teknologi yang begitu cepat memberikan banyak kemudahan dalam memperoleh dan menyampaikan informasi. Kemudahan menyampaikan informasi ditandai dengan adanya kebebasan masyarakat dalam menyampaikan pendapat melalui berbagai media informasi. Sutantohadi dkk. (2017) menyatakan bahwa saat ini masyarakat bebas menyampaikan pendapat atau opininya, baik melalui lisan, media cetak, maupun media elektronik. Kebebasan menyampaikan pendapat membawa dampak negatif jika tidak disikapi dengan bijak. Salah satu dampak negatifnya yaitus muncul berita hoaks diberbagai media informasi. Silverman (2016) menegaskan bahwa media sosial adalah sumber informasi yang paling tidak dapat diverifikasi di dunia tetapi banyak dipercaya oleh kalangan umum karena kecepatan dapat menyebarkan informasi, Lebih lanjut, Aliasan (2017) menerangkan bahwa media sosial menjadi ladang subur untuk penyebaran hoax yang sangat berbahaya. Juliswara (2017) menyatakan bahwa hoaks dapat memecah belah masyarakat yang berakibat munculnya kegaduhan diberbagai tempat. Lebih lanjut Arif (2016) menyatakan bahwa hoaks dapat dikemas dalam sebuah media dan dirancang untuk melemahkan pusatpusat kekuasaan yang ada. Keterangan tersebut menunjukkan bahwa hoaks sangatlah berbahaya sehingga perlu ada upaya keras untuk melawan hoaks.

Perlawanan terhadap hoaks dapat dilakukan dengan berbagai metode diantaranya menggunakan metode: (1) kekuasaan untuk menutup akses ruang publik dan (2) pembekalan diri dengan keterampilan berpikir kritis. Sebagai masyarakat di luar pemilik kekuasaan metode pembekalan diri adalah satu satunya cara yang tepat untuk digunakan. Pembekalan diri dengan keterampilan berpikir kritis mampu meningkatkan kewaspadaan terhadap hoaks. Hal itu sesuai dengan pendapat Juliswara (2017) yang menyatakan bahwa salah satu keterampilan yang dapat membekali diri dalam pencegahan pengaruh hoaks adalah keterampilan dalam menggunakan daya kritis dalam menerima dan memaknai informasi. Penggunaan keterampilan berpikir dapat dibentuk melalui sistem pendidikan.

Pendidikan yang berlaku di Indonesia saat ini mengarah pada peningkatan kecakapan hidup yang salah satunya adalah keterampilan berpikir kritis (kemendikbud, 2018). Keterampilan berpikir kritis dirancang dalam kurikulum sebagai capaian yang harus capai mulai dari pendidikan dasar hingga perguruan tinggi. Hal itu mengindikasikan bahwa mahasiswa diharapkan dapat memiliki kecenderungan untuk menggunakan keterampilan berpikir kritis (disposisi berpikir kritis). Namun hal itu berbeda dengan fakta yang diungkapkan As'ari (2017) yaitu sebagian besar mahasiswa (calon guru) berada pada level berpikir kritis terendah.

Park dan Rim (2018) yang menyatakan bahwa sebagian besar sarjana cenderung mengalami kesulitan dalam memproses informasi sehingga sering terjadi kesalahan menyimpulkan suatu informasi yang diterima. Faktafakta tersebut mengindikasikan perlu dilakukan studi lapangan dengan memberikan data palsu kepada mahasiswa semester 6 dan semester 4 Pendidikan Matematika Universitas Muhammadiyah Kotabumi terkait masyarakat yang terjangkit Covid di suatu daerah. Berdasarkan hasil studi lapangan diperoleh keterangan bahwa 
70 dari 71 mahasiswa percaya begitu saja dengan data yang diberikan tanpa melakukan klarifikasi apapun. Selain itu, seorang mahasiswa kurang mempercayai data tersebut dikarenakan tidak dicantumkan sumber data.

Keterangan tersebut menambah keyakinan bahwa sudah sepatutnya dilakukan pencarian akar masalah kenapa sebagian besar mahasiswa memiliki level berpikir kritis yang rendah sehingga kurang mewaspadai berita hoaks yang diterima. Penelusuran lebih dalam dilakukan dengan melakukan wawancara kepada mahasiswa dan memperoleh kesimpulan bahwa perlu ada upaya memperbaiki konten materi yang harus disampaikan kepada mahasiswa dalam bentuk perbaikan bahan ajar.

Bahan ajar yang saat ini sedang menjadi trend dalam dunia pendidikan adalah bahan ajar yang mampu digunakan dalam kondisi apapun baik dalam pembelajaran langsung maupun pembelajaran jarak jauh, baik pembelajaran synchronous maupun asyncronous, baik daring maupun luring. Salah satu bahan ajar yang dapat digunakan dalam kondisi apapun adalah bahan ajar berbentuk video pembelajaran sebagaimana yang disampaikan oleh Fauziyyah (2019) yang menyatakan bahwa kelebihan video pembelajaran adalah dapat mengatasi masalah ruang dan waktu Kelebihan lain dari video pembelajaran diantaranya: dapat mengulang-ulang materi (Ario \& Asra, 2019), jelas dan relatif mudah diingat, menarik minat belajar (Andari, 2019), serta mampu mengembangkan imajinasi.

Begitu pentingnya bahan ajar untuk meningkatkan kewaspadaan mahasiswa terhadap hoaks, maka perlu dikembangkan bahan ajar berbentuk video pembelajaran dengan konten materi yang dapat mengasah kemampuan mahasiswa dalam menganalisis kebenaran dari suatu data. Bahan ajar berbentuk video pembelajaran yang akan dikembangkan dalam penelitian ini adalah bahan ajar berbentuk video pembelajaran pada matakuliah Statistika karena matakuliah Statistik erat kaitannya dengan data sehingga dapat diberi muatan data covid-19 sebagai bekal pengetahuan mahasiswa.

Beberapa penelitian terdahulu telah banyak yang mengkaji tentang pengembangan bahan ajar seperti Muwaffaq dan Mawartiningsih (2017), Masykur, Nofrizal, dan Syazali, 2017), Sugiyanto, Utami, dan Abeng (2018), Tea (2019), serta Hodiyanto, Darma, dan Putra, 2020). Muwaffaq dan Mawartiningsih (2017), Dari semua penelitian yang telah dilakukan terkait pengembangan bahan ajar tersebut belum ada pengembangan bahan ajar yang fokus untuk mengembangkan kewaspadaan mahasiswa terhadap hoaks.

Berdasarkan uraian tersebut, perlu dilakukan pengembangan bahan ajar berbentuk video pembelajaran untuk meningkatkan Kewaspadaan Mahasiswa Muhammadiyah terhadap Hoaks. Ketertarikan penggunaan data covid-19 pada bahan ajar ini karena akhir akhir ini sangat banyak informasi mengenai data penyebaran covid-19 yang dapat digunakan pada pembelajaran statistika.

\section{METODE PENELITIAN}

Penelitian ini menggunakan model pengembangan modifikasi Borg dan Gall (1983). Pada penelitian ini hanya menggunakan 7 langkah hasil dari modifikasi dari langkah Bord and Gall yang telah dimodifikasi sesuai dengan keperluan penelitian yaitu: (1) 
observasi dan pengumpulan informasi, (2) perencanaan desain produk, (3) pengembangan desain produk, (4) validasi desain produk, (5) perbaikan desain, (6) uji coba awal dan (7) revisi produk. Penyederhanaan dan pembatasan terhadap sepuluh langkah menjadi tujuh langkah dikarenakan faktor keterbatasan tenaga, dana, dan waktu (Sugiyono, 2011).

Metode pengumpulan data menggunakan tes dan non tes. Secara rinci instrumen penelitian yang digunakan dalam penelitian ini berdasarkan tahapan pengembangan bahan ajar adalah sebagai berikut:

1. Observasi dan pengumpulan informasi: pada tahap ini, instrumen yang digunakan adalah pedoman wawancara semi terstruktur yang digunakan untuk menganalisis kebutuhan dalam pengembangan bahan ajar berbentuk video pembelajaran berbasis data Covid-19. Pada tahap ini menggunakan subjek penelitian sebanyak 12 yang terdiri dari 6 mahasiswa Pendidikan Matematika semester 4 dan 6 mahasiswa Pendidikan Matematika semester 6.

2. Validasi desain produk: instrumen yang dibutuhkan pada tahap ini adalah (1) lembar penilaian ahli yang ditujukan untuk 2 orang ahli teknologi pendidikan dan 2 orang ahli materi; dan (2) Angket tanggapan pengguna yang digunakan untuk 2 orang praktisi

3. Ujicoba produk awal: instrument yang dibutuhkan pada tahap ini adalah tes kewaspadaan terhadap hoaks untuk 24 mahasiswa semester 3 yang sedang menempuh matakuliah Statistika

Teknik analisis data yang digunakan dalam penelitian ini yaitu, deskriptif kuantitatif untuk mengolah data dalam bentuk skor dari penilaian oleh validator serta untuk mengetahui kefektifan bahan ajar dengan menggunakan uji Mann-Whitney, sedangkan deskriptif kualitatif untuk mendeskripsikan data berupa komentar saran perbaikan dari validator. Adapun teknik penilaian kelayakan dan kepraktisan untuk analisis data dengan menggunakan skala likert dengan skala penilaian 1-5. Hasil dari penilaian ahli atau prakstisi dilakukan penskoran dengan rumus menurut Arikunto (2010) yaitu :

$$
K=\frac{\sum n_{i}}{N} \times 100 \%
$$

$\sum n_{i} \quad$ : jumlah skor yang diperoleh

$\mathrm{N} \quad$ : jumlah skor maksimal

Untuk menilai kelayakan produk yang dikembangkan menggunakan kriteria pada Tabel 1.

Tabel 1. Kriteria indikator kelayakan

\begin{tabular}{cc}
\hline $\begin{array}{c}\text { Kriteria } \\
\text { kevalidan/kelayakan }\end{array}$ & Persentase \\
\hline Sangat valid (Layak) & $85 \%<\mathrm{K} \leq 100 \%$ \\
Cukup valid (Layak) & $70 \%<\mathrm{K} \leq 85 \%$ \\
Kurang valid (tidak & $50 \%<\mathrm{K} \leq 70 \%$ \\
Layak) & \\
Tidak valid (tidak & $0 \%<\mathrm{K} \leq 50 \%$ \\
Layak) & \\
\hline
\end{tabular}

Untuk menilai kepraktisa produk yang dikembangkan menggunakan kriteria pada Tabel 2.

Tabel 2. Kriteria indikator kepraktisan

\begin{tabular}{cc}
\hline $\begin{array}{c}\text { Kriteria } \\
\text { kepraktisan }\end{array}$ & Persentase \\
\hline Sangat Praktis & $85 \%<\mathrm{K} \leq 100 \%$ \\
Cukup Praktis & $70 \%<\mathrm{K} \leq 85 \%$ \\
Kurang Praktis & $50 \%<\mathrm{K} \leq 70 \%$ \\
Tidak Praktis & $0 \%<\mathrm{K} \leq 50 \%$ \\
\hline
\end{tabular}


DOI: https://doi.org/10.24127/ajpm.v10i2.3519

\section{HASIL DAN PEMBAHASAN}

\section{Observasi dan pengumpulan informasi}

Kegiatan ini dimulai dengan melakukan observasi kepada mahasiswa yang telah memperoleh materi statistik tahun 2019 yaitu mahasiswa pendidikan matematika semester 5. Kegiatan observasi dilakukan dengan cara memberikan intrumen kepada mahasiswa untuk melihat tingkat kewaspada-an terhadap hoaks. Berdasar-kan hasil pemberian instrument diketahui bahwa 10 dari 12 mahasiswa mempercayai berita hoaks tentang covid yang diberikan. Hal itu menunjukkan bahwa $83 \%$ mahasiswa masih mudah percaya begitu saja terhadap hoaks. Data tersebut menunjukkan bahwa perlu adanya pengumpulan informasi mendalam terkait apa saja yang menadi faktor utama mahasiswa mempercayai berita hoaks tersebut.

Pengumpulan informasi dilakukan dengan melakukan wawancara tidak terstruktur kepada mahasiswa dalam waktu yang hampir bersamaan dalam satu ruangan sebagaimana terlihat pada Gambar 1. Adapun hasil yang diperoleh dari kegiatan observasi menunjukkan bahwa:

a. Terdapat $83 \%$ mahasiswa kurang waspada terhadap hoaks.

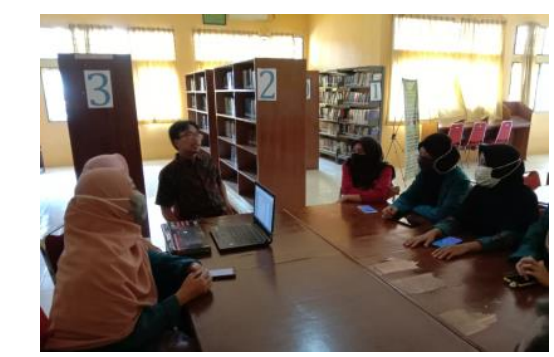

Gambar 1. Kegiatan pengumpulan informasi kepada mahasiswa

b. Terdapat $80 \%$ mahasiswa meganggap suatu informasi sahih/valid jika terdapat sumber informasi yang jelas. Hal ini menunjukkan bahwa sahih tidaknya informasi ditinjau berdasarkan literasi sumber.

c. Terdapat $17 \%$ mahasiswa yang mengganggap suatu informasi sahih/ valid jika bentuk datanya berupa data kuantitatif. Hal ini menunjukkan bahwa sahih tidaknya suatu informasi ditinjau dari literasi bentuk data

d. Hanya ada $8 \%$ mahasiswa yang menganggap suatu informasi sahih/ valid jika informasi pada data tersebut logis. Hal ini menjukkan bahwa sangat sedikit sekali mahasiswa yang menyimpulkan sahih/ tidaknya suatu data yang ditinjau dari literasi isi.

Berdasarkan keterangan tersebut terlihat bahwa terdapat beberapa factor yang menyebabkan mahasiswa kurang waspada terhadap hoaks yaitu:

a. Data yang disajikan dalam berita berupa data kuantitatif

b. Data yang disajikan menunjukkan ada sumber informasi

c. Hanya sedikit mahasiswa yang melihat informasi dianggap sahih jika data yang disajikan logis sehingga perlu dirancang sebuah bahan ajar yang dapat membimbing mahasiswa untuk menganalisis kelogisan dari informasi yang diperoleh, ketersediaan sumber informasi.

\section{Perencanaan Desain Produk}

Penelitian ini mengembangkan produk bahan ajar berbentuk video pembelajaran. Perencanaan dilakukan dengan melakukan beberapa langkah:

a. Merencanakan konten dari bahan ajar terkait dengan materi statistika yaitu materi pengertian statistika, distribusi frekuensi, tendensi sentral dan ukuran letak.

b. Merencanakan bentuk berita/ informasi yang dapat dikaitkan 
dengan materi statistika yang dipilih. Adapun bentuk berita yang dipiih adalah berita sahih tentang covid-19, berita hoaks yang memuat data berlebih, berita hoaks yang memuat data saling bertentangan serta berita hoaks yang tidak mencantumkan sumber.

c. Merencanakan kombinasi warna yang akan digunakan dalam video pembelajaran. adapun kombinasi warna yang dipilih adalah kombinasi yang dominan dengan warna hijau, coklat dan putih.

d. Merencanakan model yang berada dalam video pembelajaran yaitu mahasiswi prodi pendidikan matematika yang memiliki suara bagus dan jelas serta terbiasa tampil didepan kamera.

e. Merencanakan durasi maksimum video pembelajaran yaitu 30 menit.

\section{Pengembangan Desain Produk}

Pengembangan produk yang dilakukan dalam penelitian ini yaitu: pengembangan materi, pengembangan berita hoaks berbasis data covid-19 serta pengembangan tampilan audio visual dari bahan ajar berupa video pembelajaran. Pertama, Pengembangan materi dilakukan berdasarkan materi yang sudah ada yaitu tentang pengertian statistika, distrubusi frekuansi, tendensi sentral dan ukuran letak. Pengembangan materi/konten video terletak pada contoh dan latihan yang diberikan erat kaitannya dengan data covid-19. Kedua, pengembangan berita hoaks berbasis data covid-19 dilakukan dengan cara mengumpulkan data covid19 yang sahih dari berbagai wilayah kemudian beberapa data dikembangkan sehingga menjadi data hoaks dengan beberapa tipe yaitu berita hoaks yang memuat data berlebih, berita hoaks yang memuat data saling bertentangan serta berita hoaks yang tidak mencantumkan sumber. Ketiga, pengembangan audio visual video pembelajaran didasarkan oleh beberapa criteria: 1) teks yang disajikan terlihat dengan jelas, 2) kombinasi warna yang cerak dan menarik perhatian, 3) suara yang terdengar dengan jelas. Berdasarkan criteria tersebut maka hasil dari FGD yang dilakukan oleh beberapa dosen ditetapkan bahwa: 1) teks disajikan dengan Font 16 menggunakan warna yang kontras dengan backround; 2) kombinasi warna dominan terdiri dari hijau, coklat dan putih; 3) suara menggunakan volume standar yang ada dalam aplikasi filmora.

\section{Validasi Desain Produk}

Validator pada penelitian ini terdiri dari : (1) 2 orang konstruksi bahan ajar; (2) 2 orang ahli bahasa (3) 2 orang praktisi. Validasi pertama yang dilakukan oleh ahli konstruksi bahan ajar yaitu meliputi: Kesesuaian materi dengan RPS, Keakuratan materi, Mendorong untuk waspada terhadap hoaks, Teknik penyajian, Kelengkapan penyajian, Keruntutan alur berpikir, Desain Tampilan, dan desain isi. Dari kedua validator diperoleh hasil yang menunjukkan bahwa produk yang dikembangkan telah layak untuk digunakan dengan rincian hasil penilaian sebagaimana terlihat pada Tabel 3.

Tabel 3. Hasil validasi ahli konstruksi

\begin{tabular}{lccc}
\hline No & Skor (\%) & Keterangan & Kesimpulan \\
\hline 1 & $84,5 \%$ & Cukup Valid & Layak \\
2 & $86,4 \%$ & Sangat Valid & digunakan \\
\hline
\end{tabular}

Berdasarkan Tabel 3. Terlihat bahwa: (1) skor rata-rata penilaian dari validator 1 sebesar 84,5 sehingga berdasarkan indikator kriteria kelayakan disimpulkan bahwa produk yang dikembangkan masuk kedalam kategori 
cukup valid (cukup layak) dari segi konstruksi; (2) skor rata-rata penilaian dari validator 2 sebesar 86,4 sehingga berdasarkan indikator kriteria keyakan disimpulkan bahwa produk yang dikembangkan masuk kategori sangat baik (sangat layak) dari segi konstruksi: (3) dari. Kedua valitaor tersebut jika dihitung rata-ratanya akan diperoleh rata-rata penilaian 85,45 sehingga produk yang dikembangkan masuk ke dalam kategori sangat valid (sangat layak) dari segi konstruksi. Hasil penilaian tersebut menunjukkan bahwa produk yang telah dikembangkan layak untuk digunakan.

Validasi kedua yang dilakukan oleh ahli bahasa yaitu meliputi aspek: lugas, komunikatif, dialogis dan interaktif, kesesuaian dengan perkembangan mahasiswa serta kesesuaian dengan kaidah bahasa Indonesia. Dari kedua validator diperoleh hasil yang menunjukkan bahwa produk yang dikembangkan telah layak untuk digunakan dengan rincian hasil penilaian sebagaimana terlihat pada Tabel 4.

Tabel 4. Hasil validasi ahli bahasa

\begin{tabular}{cccc}
\hline No & Skor (\%) & Keterangan & Kesimpulan \\
\hline 1 & $88,3 \%$ & Sangat Valid & Layak \\
2 & $83,6 \%$ & Cukup Valid & digunakan \\
\hline
\end{tabular}

Berdasarkan Tabel 4. Terlihat bahwa: (1) skor rata-rata penilaian dari validator 1 sebesar 88,3 sehingga berdasarkan indikator kriteria kelayakan disimpulkan bahwa produk yang dikembangkan masuk kedalam kategori sangat valid (sangat layak) dari segi bahasa; (2) skor rata-rata penilaian dari validator 2 sebesar 83,6 sehingga berdasarkan indikator kriteria keyakan disimpulkan bahwa produk yang dikembangkan masuk kategori cukup baik (cukup layak): (3) dari. Kedua valitaor tersebut jika dihitung rata- ratanya akan diperoleh rata-rata penilaian 85,95 sehingga produk yang dikembangkan masuk ke dalam kategori sangat valid (sangat layak) dari segi bahasa. Hasil penilaian tersebut menunjukkan bahwa produk yang telah dikembangkan layak untuk digunakan.

Validasi ketiga yang dilakukan oleh praktisi yaitu meliputi aspek: kejelasan bahasa, komunikasi interaktif, menarik perhatian, mudah dipahami, memiliki petunjuk yang jelas, kejelasan suara. Dari kedua validator diperoleh hasil yang menunjukkan bahwa produk yang dikembangkan telah layak untuk digunakan dengan rincian hasil penilaian sebagaimana terlihat pada Tabel 5.

Tabel 5. Hasil validasi praktisi

\begin{tabular}{cccc}
\hline No Skor (\%) & Keterangan & Kesimpulan \\
\hline 1 & $71,4 \%$ & Cukup Valid & Layak \\
2 & $78,5 \%$ & Cukup Valid & digunakan \\
\hline
\end{tabular}

Berdasarkan Tabel 5. Terlihat bahwa: (1) skor rata-rata penilaian dari validator 1 sebesar 71,4 sehingga berdasarkan indikator kriteria kelayakan disimpulkan bahwa produk yang dikembangkan masuk kedalam kategori cukup valid (cukup layak); (2) skor ratarata penilaian dari validator 2 sebesar 78,5 sehingga berdasarkan indikator kriteria keyakan disimpulkan bahwa produk yang dikembangkan masuk kategori cukup baik (cukup layak); Hasil penilaian tersebut menunjukkan bahwa produk yang telah dikembangkan layak untuk digunakan.

\section{Perbaikan desain}

Berdasarkan rekomendasi dari hasil validasi ahli konstruksi bahan ajar, maka perlu ada perbaikan dari produk yang telah dikembangkan yaitu: 1) perlu lebih interaktif dan mendorong peserta didik/mahasiswa lebih berpikir kritis terhadap hoaks; 2) perbaiki cara penya- 
jian dan 3) konstruksi konsep lebih dipertajam.

Berdasarkan rekomendasi dari hasil validasi ahli bahasa, maka perlu ada perbaikan dari produk yang telah dikembangkan yaitu: 1) semua penggunaan kata sebaiknya menggunakan bahasa yang baku; 2) lebih menggunakan kalimat yang efektif. dan 3) Gambar lebih diperjelas.

Berdasarkan rekomendasi dari hasil validasi praktisi, maka perlu ada perbaikan dari produk yang telah dikembangkan yaitu: 1) kombinasi warna dibuat lebih cerah agar lebih menarik dan 2) perlu ada perbaikan kejelasan suara dibeberapa kata.

Perbaikan desain dilakukan atas dasar rekomendasi dari semua validator yang kemudian dikonsultasikan kembali hasil perbaikannya kepada validator. Setelah menurut validator sudah tidak ada revisi lagi maka selanjutnya dilakukan uji coba awal produk.

\section{Uji coba awal}

Uji coba awal produk dilakukan pada kelas kecil yaitu 24 mahasiswa pendidikan matematika semester 3 yang sedang menempuh mata kuliah statistika. Pada pelaksanaan uji coba dilakukan beberpa tahap yaitu: 1) pemberian pre-test; 2) pemberian produk video pembelajaran berbasis data covid-19; 3) pemberian post-test dan 4) evaluasi produk

Pada tahap pemberian pre-test mahasiswa diminta untuk mengerjakan selama 120 menit dan diperoleh hasil rata-rata nilai tentang kewaspadaan terhadap hoaks sebesar 22,32. Pada tahap pemberian produk, mahasiwa diminta untuk menonton 4 video pembelajaran yang telah dikembangkan selama 4 hari dengan catatan setiap hari hanya diperbolehkan menonton 1 video. Pada pemberian post-test, mahasiswa diminta untuk mengerjakan selama 120 menit dan diperoleh hasil rata-rata nilai tentang kewaspa-daan terhadap hoaks sebesar 64,71. Selanjutnya, berdasarkan perhitungan uji Mann-Whytney menggunakan SPSS diperoleh hasil sebagaimana terlihat pada Tabel 6 .

Tabel 6. Output perhitungan Uji Mann Whytney menggunakan SPSS

\begin{tabular}{cc}
\hline & $\begin{array}{c}\text { Nilai Kewaspadaan } \\
\text { terhadap Hoaks }\end{array}$ \\
\hline Mann-Whitney U & 16.500 \\
Wilcoxon W & 316.500 \\
Z & -5.609 \\
Asymp. Sig. (2- & .000 \\
tailed) & \\
\hline
\end{tabular}

a Grouping Variable: Pre/Post-Test

Berdasarkan Tabel 6. Terlihat bahwa nilai sig.(2-tailed) $0,000<0,05$ sehingga terlihat bahwa terdapat perbedaan yang signifikan antara hasil pre-test dan post-test. Hal itu menunjukkan bahwa bahan ajar yang dikembangkan dapat meningkatkan kewaspadaan mahasiswa terhadap hoaks. Meskipun demikian, rata-rata dari nilai post-test masih jauh dari nilai sempurna. Hal itu menandakan bahwa masih ada berita hoaks yang dipercaya oleh mahasiswa sehingga perlu dilakukan evaluasi untuk menghasilkan produk yang lebih baik. Pada tahap evaluasi, mahasiswa yang telah diminta menonton bahan ajar berupa video pembelajaran tersebut diwawancarai terkait kekurangan dari bahan ajar.

Hasil wawancara menunjukkan perlu ada perbaikan pada bahan ajar tersebut sebagaimana berikut:

1) Model yang digunakan tidak hanya satu orang dalam 4 video.

2) Ada beberapa kalimat yang terlalu cepat diucapkan sehingga perlu mengulang video untuk memahami kalimat yang diucapkan 
3) Ada beberapa data covid-19 yang kurang terlihat karena font yang digunakan agak kecil jika ditonton melalui HP

4) Perlu dibuat dua versi tampilah video yaitu video untuk versi HP dan versi Laptop agar mahasiswa lebih fleksibel dalam menggunakan perangkat pemutar video

5) Pemilihan backsound harus lebih meningkatkan motivasi seperti lagu-lagu yang sedang hits di tiktok

\section{Revisi produk}

Revisi produk dilakukan atas dasar rekomendasi yang diberikan oleh mahasiswa. Sebagian besar rekomendasi diikuti untuk dilakukan perbaikan seperti: 1) memperlambat intonasi dalam berbicara agar kalimat yang diucapkan dapat dipahami dengan sekali menonton video pembelajaran; dan 2) memperbesar gambar tentang data covid-19 dalam bahan ajar video pembelajaran. untuk beberapa rekomendasi tentang model yang ada dalam video akan dilakukan di lain waktu karena keterbatasan waktu dalam penelitian hibah ini, sedangkan untuk rekomendasi tentang bakcsound tidak dapat dilakukan karena lagu-lagu sebagian besar lagu yang sedang hits di tik-tok kurang baik untuk didengarkan dalam konteks pembelajaran. Tampilan produk yang telah dikembangkan sebelum diujicoba dapat dilihat pada Gambar 2. dan Gambar 3.

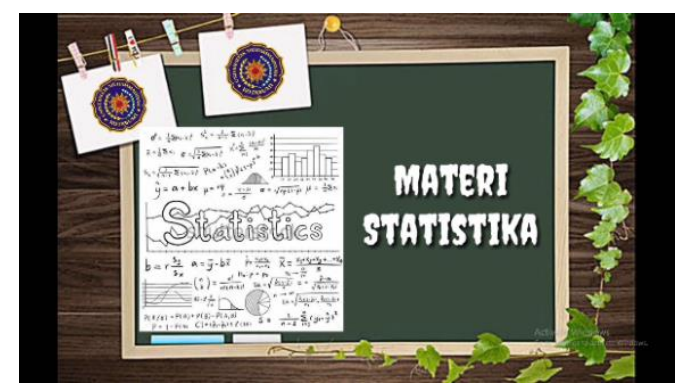

Gambar 2. Tampilan awal video pembelajaran

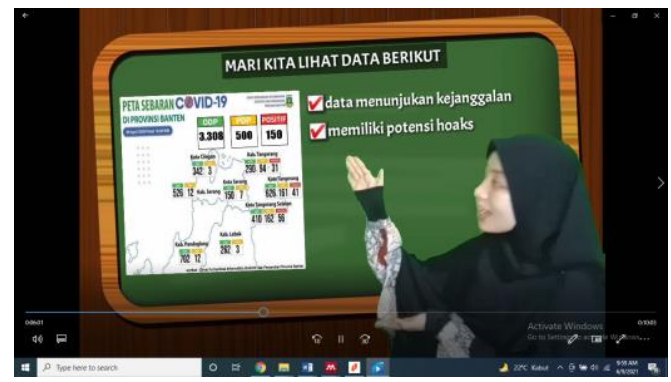

Gambar 3. Tampilan penyajian data

Covid-19 dalam video pembelajaran

Berdasarkan

proses pengembangan yang telah dipaparkan, terlihat bahwa hasil pengembangan produk berdasarkan penilaian ahli dan praktisi adalah layak digunakan dengan kategori sangat baik. Hasil dari ujicoba terbatas diperoleh hasil bahwa produk yang telah dikembangkan dapat meningkat-kan kewaspadaan terhadap hoaks secara signifikan.

Peningkatan

kewaspadaan terhadap hoaks mahasiswa yang terjadi dikarenakan mahasiswa dibiasakan menghadapi informasi yang tidak logis. Informasi tidak logis mendorong mahasiswa untuk selalu menganalisis, memverifikasi kelogisan data pada informasi yang diterima. Kebiasaan tersebut memicu mahasiswa untuk menggunakan keterampilan berpikir kritis. Keterampilan berpikir kritis mahasiswa dapat menjadikan mahasiswa semakin waspada terhadap hoaks. Hal itu sesuai dengan Juliswara (2017) yang memaparkan bahwa salah satu keterampilan yang dapat meningkatkan kewaspadaan terhadap hoaks adalah keterampilan berpikir kritis.

Hasil penelitian ini menunjukkan bahwa bahan ajar berbentuk video merupakan bahan ajar yang cukup efektif dalam mencapai tujuan pembelajaran yang diinginkan. Hal itu sesuai dengan beberapa penelitian yang telah dilakukan sebelumnya seperti Guswiani dkk (2018), Ario \& Asra (2019), dan Ridha (2021). 
DOI: https://doi.org/10.24127/ajpm.v10i2.3519

\begin{abstract}
Guswiani dkk (2018) mengungkapkan bahwa video pembelajaran cukup efektif dalam meningkatkan motivasi dan hasil belajar siswa. Video pembelajaran dapat mendorong seseorang untuk melakukan suatu tindakan sebaik mungkin. Ario menambakan bahwa video pembelajaran cukup efektif dalam memberikan pemahaman kepada mahasiswa dalam mempelajarai materi pelajaran. Lebih lanjut Ridha (2021) menyatakan bahwa Media video pembelajaran efektif dilaksanakan pada masa pandemi Covid-19, karena memudahkan pendidik dalam mengajarkan materi serta memudahkan peserta didik memahami materi pembelajaran.

Hasil pemaparan tersebut menunjukkan bahwa video pembelajaran memiliki dampak yang sangat baik dalam membantu pendidik dalam mewujudkan tujuan pembelajaran yang diinginkan baik dalam peningkatan motivasi, hasil belajar maupun kewaspadaan seseorang terhadap hoaks.
\end{abstract}

\section{KESIMPULAN DAN SARAN Kesimpulan}

Berdasarkan hasil dan
pembahasan penelitian maka kesimpulan dari penelitian ini adalah: (1) bahan ajar berbentuk video pembelajaran berbasis data covid-19 yang dikembangkan layak untuk digunakan dengan kategori penilaian sangat baik, dan (2) capaian pembelajaran mahasiswa Univeristas Muhammadiyah Kotabumi terkait kewaspadaan terhadap hoaks cukup baik jika didasarkan pada hasil uji Mann-whitney yang menyimpulkan bahwa ada peningkatan kewaspadaan mahasiswa terhadap hoaks yang signifikan.

\section{Saran}

1) Hasil penelitian ini dapat dilanjutkan ke tahap pengembangan selanjutnya yaitu pengujian lapangan operasional, revisi produk berdasarkan hasil pengujian lapangan operasional, dan desiminasi produk

2) Hasil penelitian ini dapat dijadikan pelajaran bagi peneliti selanjutnya dalam mengembangkan bahan ajar berupa video pembelajaran terkait 7 tahapan pengembangan yang telah dilakukan

\section{UCAPAN TERIMAKASIH}

Ucapan terimakasih kami haturkan kepada semua pihak yang terlibat dalam penyelesaian penelitian ini terutama kepada Majelis Diktilitbang PP Muhammadiyah yang telah membantu pendanaan melalui program Hibah RisetMu Batch 4.

\section{DAFTAR PUSTAKA}

Aliasan. (2017). Pengaruh Pemahaman Keagamaan dan Literasi Media terhadap Penyebaran Hoax di Kalangan Mahasiswa. Jurnal Komunikasi Islam Dan Kehumasan, 1(2), 126-147.

Andari, I. Y. (2019). Pentingnya Media Pembelajaran Berbasis Video untuk Siswa Jurusan IPS tingkat SMA se-Banten. Prosiding Seminar Nasional Pendidikan FKIP, 2(1), 263-275. https://jurnal.untirta.ac.id/index.ph p/psnp/article/download/5765/4138

Arif, R. (2016). Internet As a Hope or a Hoax for Emerging Democracies : Revisiting the Concept of Citizenship in The Digital Age. Social and Behavioral Sciences, 236. https://doi.org/10.1016/j.sbspro.20 16.12.002 
DOI: https://doi.org/10.24127/ajpm.v10i2.3519

Arikunto, S. (2010). Prosedur Penelitian Suatu Pendekatan Praktik. PT Rineka Cipta.

Ario, M., \& Asra, A. (2019). Pengembangan Video

Pembelajaran Materi Integral pada Pembelajaran Flipped Classroom. AKSIOMA: Jurnal Program Studi Pendidikan Matematika, 8(1), 2031.

https://jurnal.untirta.ac.id/index.ph p/psnp/article/download/5765/4138

As'ari, A. R., Mahmudi, A., \& Nurlaelah, E. (2017). Our Prospective Mathematic Teachers Are Not Critical Thinkers Yet. Journal on Mathematics Education Mathematics Education, 8 (2), 145-156.

https://doi.org/10.22342/jme.8.2.39 61.145-156

Borg, W. R., \& Gall, M. D. (1983). Educational Research An Introduction (Fourth Edi). Longman.

Fauziyyah, Z. (2019). Pengembangan Media Video Pembelajaran untuk Meningkatkan Keterampilan Menyimak dan Berbicara Siswa kelas III SDN Merjosari 2 Malang (Doctoral dissertation, Universitas Islam Negeri Maulana Malik Ibrahim). Retrieved from http://etheses.uinmalang.ac.id/166.

Guswiani, W., Darmawan, D., Hamdani, N. A., \& Noordyana, M. A. (2018). Efektivitas Penggunaan Video Pembelajaran Dalam Pembelajaran Front Office Di Kelas XI Akomodasi. JTEP-Jurnal Teknologi Pendidikan Dan Pembelajaran, 3(September), 688698.

Hodiyanto, Darma, Y., \& Putra, S. R. S. (2020). Pengembangan Media Pembelajaran Berbasis
Macromedia Flash Bermuatan

Problem Posing terhadap

Kemampuan Pemecahan Masalah

Matematis. Jurnal Pendidikan

Matematika, 9(2), 323-334.

Juliswara, V. (2017). Mengembangkan

Model Literasi Media yang

Berkebhinnekaan dalam

Menganalisis Informasi Berita

Palsu (Hoax) di Media Sosial.

Jurnal Pemikiran Sosiologi, 4(2), 142-164.

Masykur, R., Nofrizal, \& Syazali, M. (2017). Pengembangan Media Pembelajaran Matematika dengan Macromedia Flash. Jurnal Pendidikan Matematika, 8(2), 177-186.

Muwaffaq, A., \& Mawartiningsih, L. (2017). Pengembangan Media Pembelajaran Macromedia Flash 8 Berbasis Pendekatan Konsep Development of Macromedia Flash 8 Learning Media Based Concept Approach. Proceeding Biology Education Conference, 14(1), 441447.

Park, K., \& Rim, H. (2018). Social Media Hoaxes, Political Ideology, and The Role of Issue Confidence. Telematics and Informatics, 38(November), 1-11. https://doi.org/10.1016/j.tele.2018. 11.001

Ridha, M. (2021). Efektifitas Penggunaan Media Video pada Pembelajaran Tematik Terpadu di Sekolah Dasar Saat Pandemi Covid-19. Jurnal Pendidikan Tambusai, 5(1), 154-162. https://jptam.org/index.php/jptam/a rticle/view/925

Silverman, C. (2016). Lies, Damn Lies , and Viral Content. Tow Center for Digital Journalism.

Sugiyanto, R., Utami, A., \& Abeng, A. T. (2018). Pembuatan Media 
DOI: https://doi.org/10.24127/ajpm.v10i2.3519

Pembelajaran Berbasis Vidio untuk Guru Sekolah Dasar Kota Palangka Raya. Jurnal Pengabdian Kepada Masyarakat, 2(2), 196-201.

Sutantohadi, A., \& Wakhidah, R. (2017). Bahaya Berita Hoax dan Ujaran Kebencian pada Media Sosial terhadap Toleransi. Pengabdian Kepada Masyarakat, 1(1), 1-5.

Tea, F. G. (2019). Pengembangan Video Pembelajaran Menggunakan Software Wondershare Filmora pada Mata Pelajaran Sejarah Kelas X Sekolah Menengah Atas Negeri 3 Palembang (skripsi, Universitas Sriwijaya). Retrieved from

https://repository.unsri.ac.id/3186/ . Universitas Sriwijaya. 